\title{
这 UNIVERSITEIT VAN AMSTERDAM \\ De Netwerkstructuur van Resilience: \\ Positief Affect in Relatie tot Emoties
}

Auteur: Jasper Naberman

\#: 10787224

Programmagroep: $\quad$ Psychologische Methodenleer

Begeleiding: $\quad$ G. Lunansky

Tweede correctie: J. Kruis

Aantal woorden: $\quad 4169$

Aantal woorden abstract: 119 


\begin{abstract}
In deze studie is gekeken naar de netwerkstructuur van resilience. Hiervoor is gebruik gemaakt van netwerkanalyse om enkele eigenschappen van resilience in netwerkmodellen te schatten. Extra aandacht is er voor positief affect, welke naar de broaden-and-build theory of positive emotions (Fredrickson, 1998) een centrale rol zou spelen in resilience. Er deed een totaal van 31 deelnemers mee waarbij twee weken lang driemaal daags time series data werd afgenomen naar de experience sampling method. Er werden temporal en contemporaneous individuele netwerkmodellen geschat, waaruit bleek dat positief affect een minder centrale rol vertolkt dan op basis van de broadenand-build theory of positive emotions werd verwacht. De aanwezigheid van partiële correlaties geeft een indicatie van causaliteit tussen de knopen van de netwerken.
\end{abstract}

\title{
Inleiding
}

Psychologische resilience laat zich in het Nederlands vertalen als veerkrachtigheid of rekbaarheid. Het houdt het vermogen in na een heftig emotionele of zelfs traumatiserende ervaring een stabiel equilibrium, ook wel evenwicht, van psychologisch welzijn te behouden. In dit onderzoek zal worden gekeken naar het behouden van een positief psychologisch equilibrium aan de hand van resilience, wat aangenomen wordt bij toekomstige vermeldingen van het begrip resilience. Volgens Bonanno (2004) verschilt resilience van iets als herstellingsvermogen omdat er bij resilience bijna, tot helemaal geen sprake is van een periode van sub-normaal functioneren. Dit in tegenstelling tot werkelijk herstellingsvermogen, waarbij individuen een periode van mogelijk drempel overschrijdende psychopathologie kennen maar in staat zijn daarvan te herstellen. Resilience wordt ook gezien als een beschermende factor, welke ervoor zorgt dat individuen zich op gebruikelijke wijze kunnen 
ontwikkelen en positieve uitkomsten verzorgt onder kinderen die worden blootgesteld aan negatieve situaties (Luthar, Cicchetti \& Becker, 2000; Masten, 2001).

De set aan eigenschappen die wordt omschreven als onderdeel van resilience zorgt ervoor dat mensen na een traumatische ervaring op origineel niveau kunnen blijven functioneren, wat voor een individu en zijn omgeving erg belangrijk kan zijn. Zo vond Fredrickson, Tugade, Waugh en Larkin (2003) dat volwassenen met een hogere mate van resilience na de aanslagen op 11 september 2001 in de Verenigde Staten minder depressief waren dan volwassenen met een mindere mate van resilience, en een hogere frequentie van positieve emoties voelden in de nasleep van de aanslagen. Hieruit blijkt dat een vergroot inzicht in de dynamiek en structuur van resilience van groot maatschappelijk belang kan zijn. Het netwerkperspectief is bij uitstek geschikt om dit inzicht te verschaffen.

Het netwerkperspectief over psychologische diagnostiek ziet psychopathologieën als causale netwerken bestaande uit symptomen en directe causale relaties daartussen (Borsboom, 2008). Resilience kan ook via dit systeem bekeken worden, waarbij de constructen die ten grondslag liggen aan resilience kunnen worden gezien als knopen in het netwerk en de invloeden die de constructen op elkaar hebben als de relaties tussen de knopen. Zo zou een positieve emotie als blijdschap invloed kunnen hebben op een negatieve emotie als verdriet, en kan activatie van de knoop 'blijdschap' in een netwerk via relaties in dat netwerk kunnen zorgen voor deactivatie van de knoop 'verdriet'. Om goed te kunnen begrijpen hoe een netwerk in elkaar steekt zijn de relaties tussen de knopen van groot belang (Borsboom \& Cramer, 2013). In dit onderzoek zal worden gekeken naar de relaties en knopen van de netwerkstructuur van resilience. 
Uit een simulatiestudie van Cramer et al. (2016) bleek dat een netwerk zelf kan worden gezien als resilient als er sprake is van lage partiële correlaties of kleine causale verbanden tussen de knopen van het netwerk. In de studie kwam naar voren dat individuen meer kans hebben een pathologie te ontwikkelen als er sprake is van sterke connecties in een netwerk. Iemand kan zich dan al heel moe voelen na één nacht slecht slapen. Externe stimuli, zoals bijvoorbeeld stress, zorgen ervoor dat een individu makkelijker een bepaalde pathologie ontwikkelt. Als een netwerk zwakke connecties heeft zal het manipuleren van één van de knopen niet makkelijk effect hebben of doorwerken op de rest van het netwerk, waardoor het netwerk als geheel resilient is. Als een netwerk echter al meerdere geactiveerde knopen heeft, door bijvoorbeeld een traumatische gebeurtenis, is nog niet bekend hoe zo'n netwerk dan weer terug kan keren naar de originele staat. Dit komt omdat de daadwerkelijke netwerkstructuur van resilience nog niet bekend is. Als iemand echter een aantal knopen aan heeft staan, een periode van sub-normaal functioneren kent, en vervolgens weer de originele status van het netwerk bereikt, lijkt dit meer op herstellingsvermogen dan op resilience.

Er zijn nog geen eerdere onderzoeken geweest naar de netwerkstructuur van resilience. De relatief nieuwe visie van psychologische constructen als dynamische systemen bestaande uit de symptomen van die fenomenen kan op het gebied van resilience meer inzicht geven in hoe het construct in elkaar steekt. Met inzicht in de netwerkstructuur van resilience is het wellicht mogelijk de mate van resilience in een individu te verhogen, om zo de positieve uitkomsten die met een hoge mate van resilience geassocieerd zijn te bewerkstelligen. Dit kan door preventieve therapieën te richten op specifieke knopen zodat een netwerkstructuur zich vormt naar de gewenste mate van resilience. Als bijvoorbeeld blijkt dat bij een gegeven individu de knoop 'ongerustheid' een bepalende rol speelt in het netwerk, kan een therapie zich richten op 
het verminderen van 'ongerustheid'. Hierdoor kan het individu meer resilience opbouwen en beter bestand worden tegen tegenslagen.

Resilience is een erg complex construct, wat beïnvloed wordt door veel verschillende factoren, zoals optimisme, flexibiliteit en aanpassingsvermogen in negatieve situaties (Wagnild \& Collins, 2009; Werner, 1995). Resilience wordt onder oudere volwassenen onder andere geassocieerd met vergevingsgezindheid (Broyles, 2005), het hebben van een levensdoel, een gevoel van coherentie en zelftranscendentie (Nygren et al., 2005). Resilience is een erg prevalente eigenschap (Masten, 2001) welke ook deels wordt bepaald door positieve emotie (Fredrickson, 2001; Fredrickson et al., 2003). Volgens de broaden-and-build theory of positive emotions (Fredrickson, 1998) zorgen positieve emoties als blijdschap, interesse, tevredenheid en liefde voor een verhoging van psychologische resilience binnen individuen (Fredrickson, 1998; 2001). Ook worden individuen na het ervaren van positieve emoties beter in staat om om te gaan met stress en andere negatieve emotionele ervaringen (Tugade \& Fredrickson, 2004).

De hier boven genoemde factoren uit de broaden-and-build theory of positive emotions werken veelal op de lange termijn. Of iemand over het algemeen tevreden is fluctueert waarschijnlijk niet om de paar uur. Toch is het voor dit onderzoek van belang dat er op korte termijn genoeg variatie plaatsvindt binnen een construct, omdat alleen dan de korte termijn relaties tussen verschillende knopen in een netwerk kunnen worden blootgelegd. Dit is wenselijk omdat wordt verwacht dat de eigenschappen die samen resilience vormen op korte termijn zullen fluctueren. Van een fenomeen zoals bijvoorbeeld geïrriteerdheid wordt verwacht dat de mate die een individu hiervan ervaart een klein variantie-interval kent. Dit houdt in dat de mate van irritatie die een individu ervaart om de paar uur verschilt, waarbij het wenselijk is dat het ratio 
metingen en de intervallen tussen deze metingen hiermee samenvalt. Met data die meermaals per dag bij een individu kan worden afgenomen kan per participant een uniek netwerk worden geschat (Epskamp et al., 2017). Om deze redenen is voor de operationalisatie van liefde gekozen voor positief affect. Een individu kan op dagelijkse basis voor verscheidene subjecten een fluctuerende mate van positieve affectie ervaren, wat het een voor dit onderzoek geschikte operationalisatie van liefde maakt.

Een te verwachten eigenschap in de netwerkstructuur van resilience is het ontstaan van zogeheten feedbackloops. Dit zijn eigenschappen van een netwerk waarbij het variëren van één van de knopen indirect, via de rest van het netwerk, invloed kan hebben op diezelfde knoop, waardoor feedback ontstaat. Zo kan een positieve emotie als enthousiasme een negatieve emotie als een gevoel van stress verminderen, en kan het verminderde stressniveau er weer voor zorgen dat een individu nog enthousiaster wordt (Fredrickson, 2003; Tugade \& Fredrickson, 2004).

$\mathrm{Al}$ met al is resilience een gecompliceerd fenomeen wat door verscheidene factoren beïnvloed wordt en geen eenzijdige oorzaak kent. Deze multilaterale aard, de fluctuering over tijd en het gegeven dat feedbackloops zouden kunnen voorkomen, maakt het construct bij uitstek geschikt om onderzocht te worden aan de hand van de dynamische systeemtheorie en netwerkanalyse. Verwacht wordt dat positief affect een centrale rol speelt in het netwerk van resilience. Ook wordt verwacht dat positief affect zal samenhangen met andere positieve emoties. Over het algemeen wordt als hypothese gesteld dat positieve emoties onderling positieve partiële correlaties zullen kennen, en negatieve partiële correlaties met negatieve emoties. Van negatieve emoties wordt verwacht dat ze positief zullen samenhangen met andere negatieve emoties, en negatief met positieve emoties. Verwacht wordt dat al deze eigenschappen zowel in de individuele als in de collectieve netwerken terug te vinden zijn. 


\section{Methoden}

\section{Deelnemers en Materialen}

Een uiteindelijk totaal van 31 deelnemers deden mee aan deze studie.

Deelnemers werden geworven via een participatieprogramma van de Faculteit der Maatschappij- en Gedragswetenschappen aan de Universiteit van Amsterdam, LAB. Individuen kregen hiervoor een totaal van 4.5 research credits, waar een propedeusestudent in één jaar een totaal van 10 dient te halen. Deelnemers werden ook geworven uit persoonlijke kringen van de onderzoekers, ofwel middels een convenience sample. Alle deelnemers zijn vooraf grondig schriftelijk ingelicht over het verloop van de studie en zijn akkoord gegaan door een informed consent te tekenen. Er is in dit onderzoek één conditie aanwezig, aangezien de deelnemers niet op experimentele wijze gemanipuleerd zullen worden. Er hebben 26 deelnemers voor gekozen demografische informatie vrij te geven. Onder deze deelnemers waren 17 vrouwen en 9 mannen en was de gemiddelde leeftijd 29.577 jaar, met een standaarddeviatie van 15.608 jaar. De standaarddeviatie ligt vrij hoog vanwege enkele deelnemers met een leeftijd van boven de 50 jaar.

Voor het meten van de verschillende constructen, welke later de knopen in het netwerk zullen gaan vormen, is voor een intensieve manier van time series dataverzameling gekozen, waarbij dagelijks fluctuerende eigenschappen goed kunnen worden waargenomen: de experience sampling method (ESM; Myin-Germeys et al., 2009; Aan het Rot, Hogenelst \& Schoevers, 2012). Met ESM worden deelnemers herhaaldelijk gemeten binnen korte tijdsintervallen, wat een inzicht geeft in het dagelijks leven (Epskamp et al., 2017). In dit onderzoek zullen de deelnemers twee weken lang en driemaal daags een korte vragenlijst invullen om uiteindelijk 42 meetmomenten te voltooien. Op dagelijkse basis is dat 's ochtends tussen 08:00 uur en 11:00 uur, 's 
middags tussen 13:00 uur en 16:00 uur en 's avonds tussen 19:00 uur en 22:00 uur. De deelnemers zullen in staat worden gesteld op hun smartphone een applicatie te downloaden waarmee ze de vragenlijst kunnen invullen. Op van tevoren aangegeven tijdstippen zullen de deelnemers een herinnerende notificatie ontvangen als de vragenlijst van dat tijdstip nog niet is ingevuld. De vragenlijst is bedoeld om twaalf verschillende affect-states te meten. Voor elke affect-state zal een deelnemer een stelling gepresenteerd krijgen, waarna hij/zij moet aangeven in hoeverre die stelling op hem/haar van toepassing is. Dit gebeurt aan de hand van een 7-punts Likertschaal. De afkortingen van de 12 affect-states en hun bijbehorende stellingen zijn als volgt:

- 'WOR': I am worrying.

- 'SAT': I am satisfied.

- 'CHE': I am cheerful.

- 'ENE': I feel full of energy.

- 'UNS': I feel unsure.

- 'REL': I feel relaxed.

- 'AGI': I feel agitated.
- 'ANG': I am angry.

- 'IRR': I am irritated.

- 'QUI': I feel quiet.

- 'ENT': I feel enthusiastic.

- 'POS': I feel positive affection towards something or someone.

\section{Analyseplan}

Wanneer gewerkt wordt met data welke verzameld is met behulp van ESM is een risico dat opeenvolgende meetmomenten waarschijnlijk niet onafhankelijk zijn (Epskamp et al., 2017). Een manier om hiermee om te gaan is het lag-1 vector autoregression (VAR) model (Van der Krieke et al., 2015). De uitkomst van dit model kan worden weergegeven in een netwerkstructuur. Hierbij wordt er een link tussen twee knopen weergegeven op het moment dat een waarde van een knoop op het ene moment de waarde van een andere knoop op een daaropvolgend moment kan voorspellen (Epskamp et al., 2017). Het dan gevormde netwerk heet een temporeel netwerk. De 
links tussen de verscheidene knopen in dit netwerk voldoen aan de uit de econometrische literatuur stammende Granger causality (Granger, 1969, aangehaald in Epskamp et al., 2017), waarbij een mogelijke oorzaak voorafgaat aan een mogelijk gevolg en zo een indicatie van causaliteit kan geven. De individuele netwerken zullen worden geschat met de graphicalVAR package (Epskamp, 2017) voor de statistische softwareomgeving R. De collectieve netwerken zullen worden geschat met de mIVAR package (Epskamp, Deserno \& Bringmann, 2017). De Bayesian Information Criterion (BIC) zal worden gebruikt om het best fittende model te kiezen. Het gekozen model zal opnieuw worden gefit als een latent netwerkmodel (LNM; Epskamp, Rhemtulla, \& Borsboom, 2017) met behulp van de lvnet package voor R. Een LNM is een generalisatie van structural equation modeling dat ervoor zorgt dat ook verbindingen tussen knopen zonder richting in het netwerk kunnen worden opgenomen (Epskamp et al., 2017). 


\section{Resultaten}

Aan het onderzoek hebben uiteindelijk een totaal van 31 deelnemers meegedaan. Een aantal deelnemers hebben echter slechts één of een paar metingen voltooid voor zich terug te trekken. De studie kende een uiteindelijke gemiddelde response rate van $\mu=81.941 \%$ en een standaarddeviatie van $\sigma=29.419$. Een histogram van de response rates is terug te vinden in Figuur 1.

\section{Response Rates}

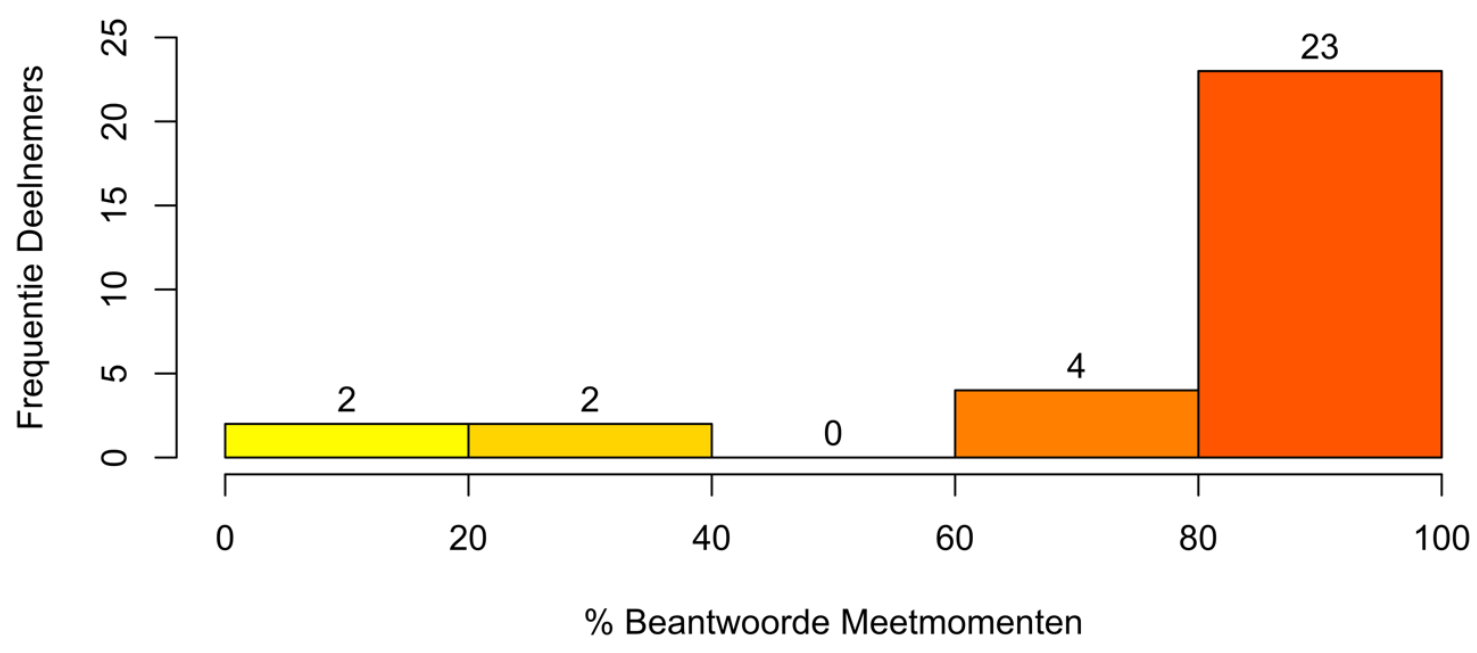

Figuur 1. Histogram met Response Rates van de Deelnemers.

In Figuur 1 is te zien dat veruit de grootste groep van 23 deelnemers 80 tot $100 \%$ van de metingen heeft beantwoord. Wanneer deelnemers een meting zijn vergeten, of één van de vragen in de meting hebben overgeslagen is deze meting in zijn geheel uit de dataset verwijderd. In totaal waren er 6 deelnemers die 100\% van de metingen hebben voltooid. Voor het schatten van individuele netwerken zijn ter illustratie twee van de deelnemers met een 100\% response rate uitgekozen. Deze zullen hierna persoon A en persoon B genoemd worden. Voor beide deelnemers zijn twee soorten netwerken geschat. Allereerst een comtemporaneous netwerk, waarbij wordt gekeken of knopen elkaar voorspellen op hetzelfde meetmoment, en een temporal netwerk, waarbij wordt gekeken of knopen elkaar over tijd kunnen voorspellen. De twee netwerken van persoon 
A en persoon B zijn terug te vinden in respectievelijk Figuur 2 en Figuur 3. De

bijbehorende centraliteitsplots van persoon A en persoon B zijn terug te vinden in Figuur 4 en Figuur 5.

De netwerken zijn geschat met parameter $\lambda($ lambda) $=50$, de standaard van de graphicalVAR package. Deze parameter controleert de sparsity van het netwerk en zorgt er met deze waarde voor dat er 2500 modellen worden geëvalueerd voor het temporal netwerk. De package maakt ook gebruik van de extended Bayesian information criterion (EBIC) voor modelselectie. In welke mate de EBIC simpelere modellen de voorkeur geeft wordt bepaald aan de hand van hyperparameter $\gamma$ (gamma). Met een hogere waarde van $\gamma$ worden simpelere modellen (minder connecties) geprefereerd. Aangezien deze studie voornamelijk een exploratieve studie is op het gebied van netwerkanalyse van resilience is in alle gevallen gekozen voor $\gamma=0$, wat ervoor zorgt dat de gewone Bayesian information criterion (BIC) wordt gebruikt voor modelselectie. Dit is nog steeds een criterium dat simpelere modellen de voorkeur geeft, overfitting tegengaat en daarmee voor meer sparsity zorgt dan in een partiële correlaties netwerk zonder vorm van regularisatie (Epskamp \& Fried, 2016), maar op deze manier worden meer connecties in het model geschat dan bij hogere waarden van $\gamma$.

Bij persoon A zijn in het contemporaneous netwerk (de linker plot) meer relaties tussen de knopen zichtbaar dan in het temporal netwerk (de rechter plot). In het temporal netwerk is te zien dat wanneer persoon A geïrriteerd ('IRR') is op het ene moment hij op een later moment boos ('ANG') wordt. Ook is te zien dat het zich zorgen maken ('WOR') en het zich ontspannen voelen ('REL') respectievelijk een positieve en een negatieve partiële correlatie hebben met het zich onzeker ('UNS') voelen van persoon A. Wanneer persoon A zich stil voelt ('QUI') op het ene moment en daarmee later minder positief affect ('POS') ervaart, leidt tot de sterkste negatieve partiële 

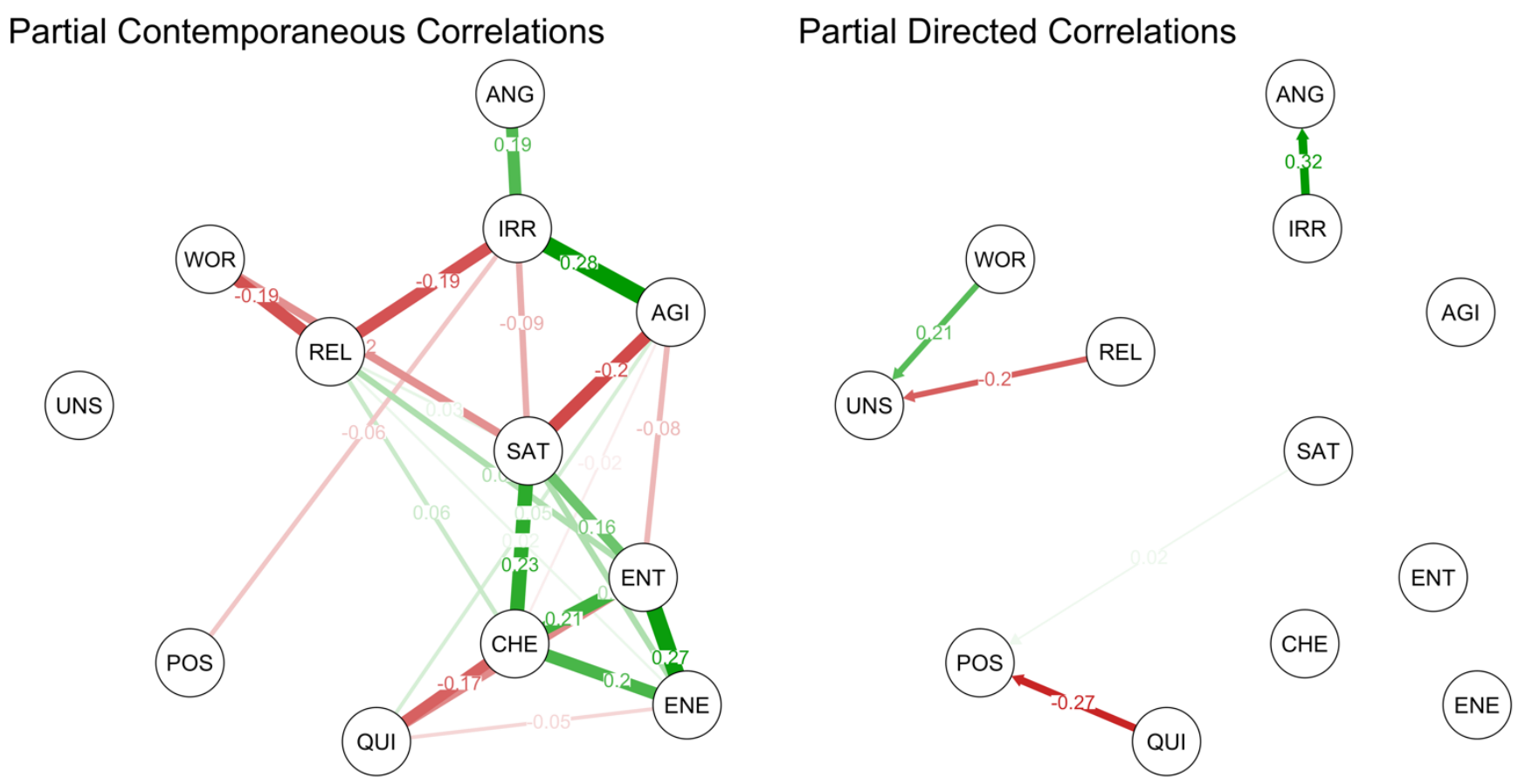

Figuur 2. Netwerkstructuren van Persoon A. Links het Contemporaneous Netwerk, Rechts het Temporal Netwerk.
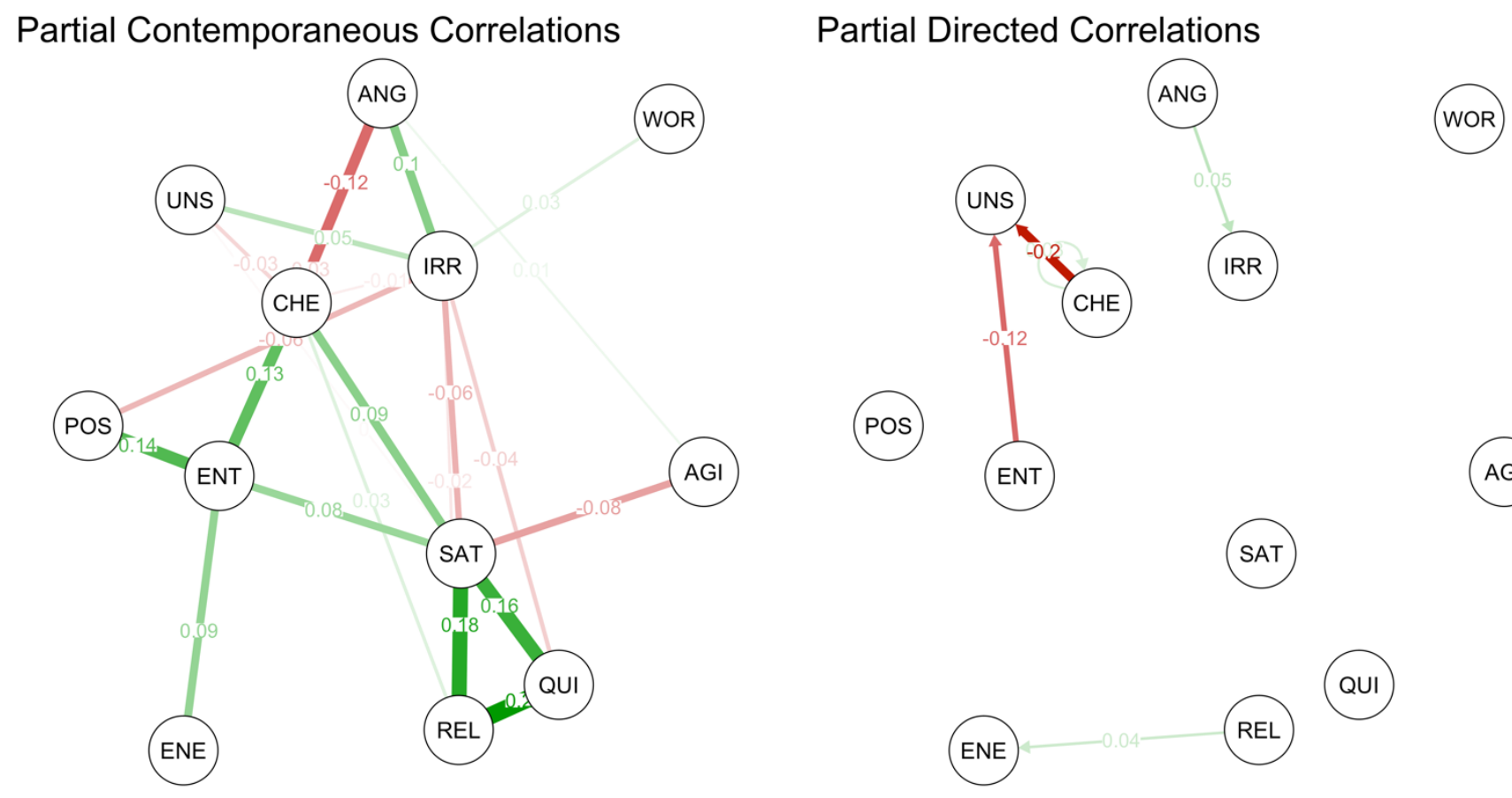

Figuur 3. Netwerkstructuren van Persoon B. Links het Contemporaneous Netwerk, Rechts het Temporal Netwerk. 


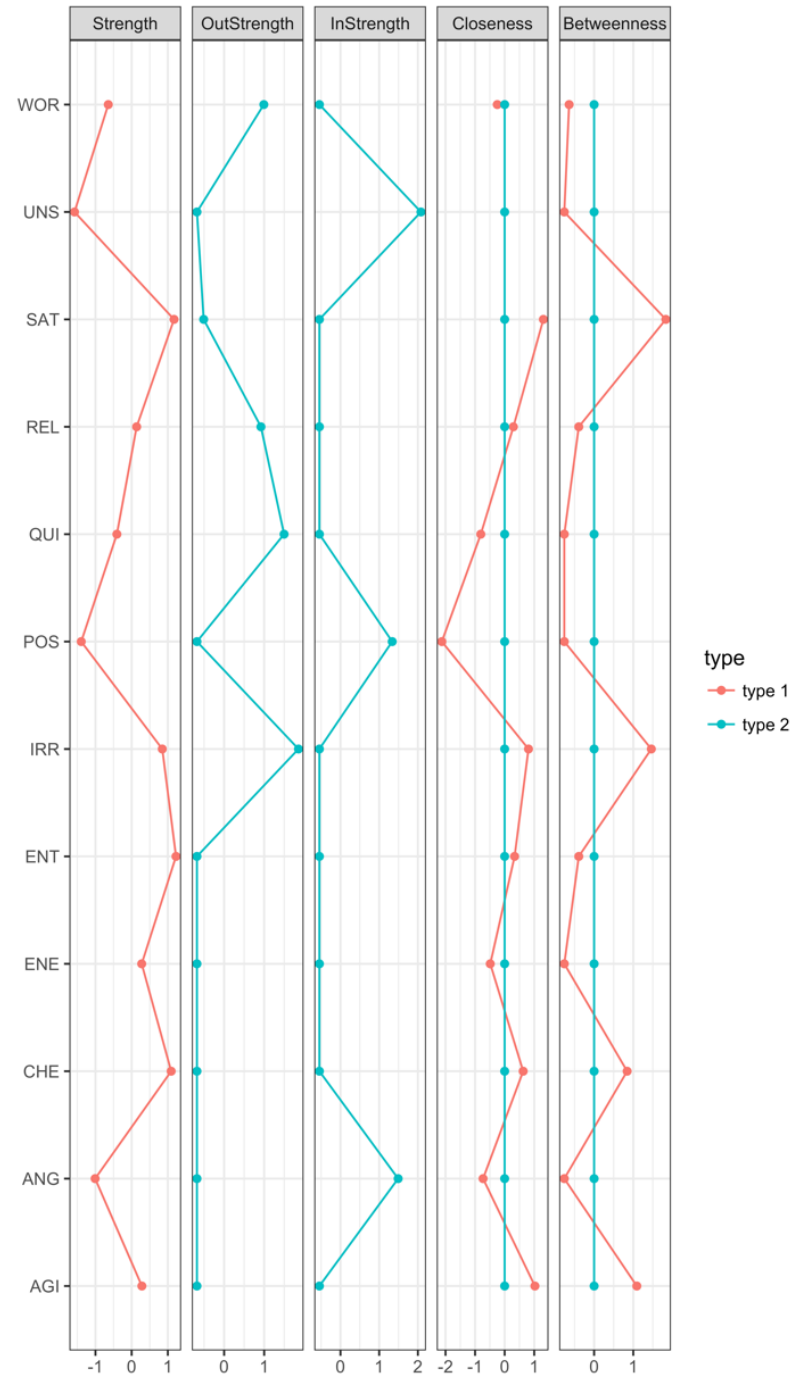

Figuur 4. Gestandaardiseerde Centraliteitsplot Netwerkknopen Persoon A. De X-As Laat Z-Scores Zien.

Type 1 = Contemporaneous Netwerk, Type 2 = Temporal Netwerk

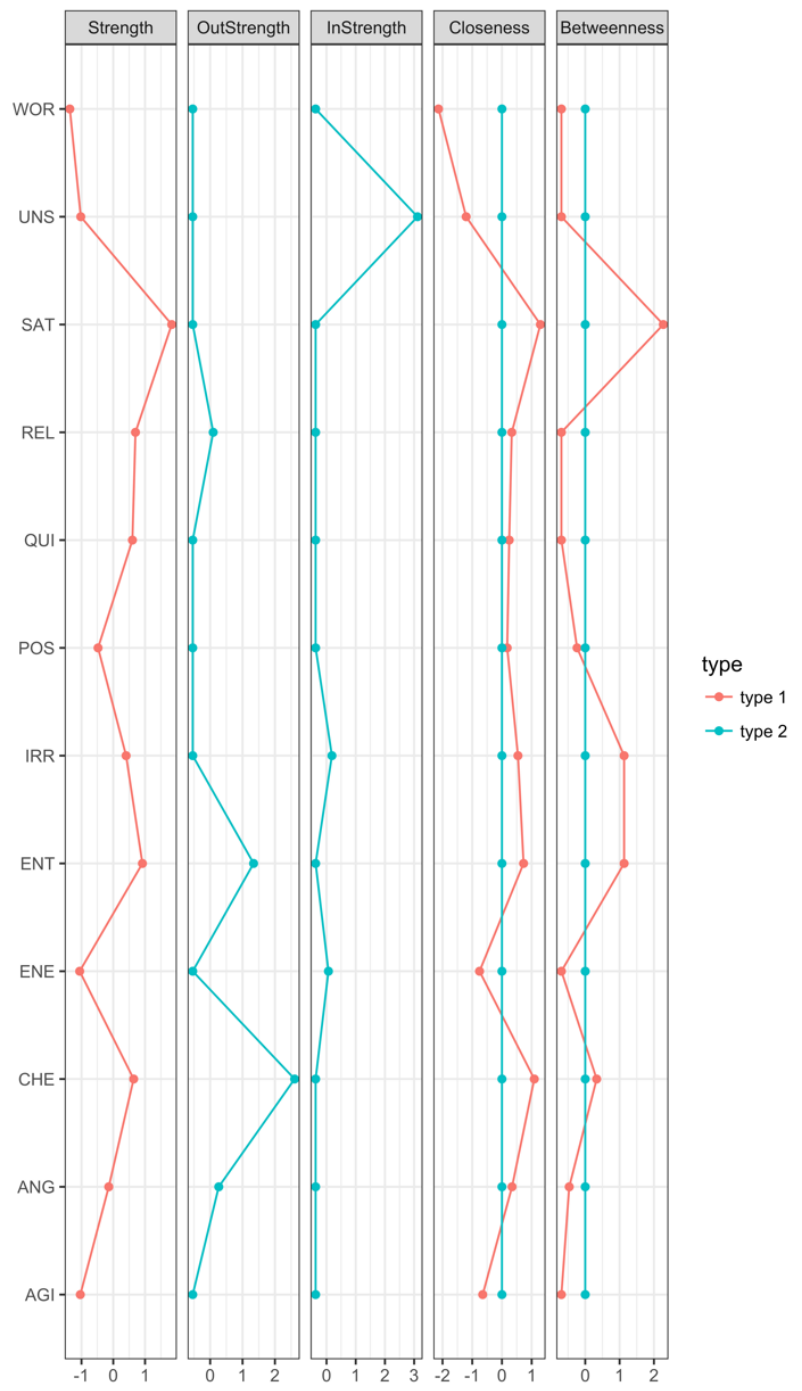

Figuur 5. Gestandaardiseerde Centraliteitsplot Netwerkknopen Persoon B. De X-As Laat Z-Scores Zien.

Type 1 = Contemporaneous Netwerk, Type 2 = Temporal Netwerk

correlatie in het temporal netwerk van persoon A. Dit zou kunnen worden verklaard omdat positief affect en liefde volgens de broaden-and-build theory of positive emotions samenhangt met blijdschap en interesse, welke kunnen worden gezien als tegenhangers van het zich stil voelen. In het contemporaneous netwerk van persoon A zijn tevredenheid ('SAT'), opgewektheid ('CHE'), irritatie ('IRR') en enthousiasme ('ENT') centrale knopen in het netwerk. Dit is ook terug te zien in de centraliteitsplot van persoon A, waarbij deze knopen bijna allemaal een Z-score van 1 of meer halen. 
Ook voor de netwerkstructuren van persoon B geldt dat het contemporaneous netwerk meer relaties tussen de knopen kent dan het temporal netwerk. In het temporal netwerk is te zien dat wanneer persoon B zich opgewekt ('CHE') of enthousiast ('ENT') voelt hij zich waarschijnlijk op een later moment minder onzeker ('UNS') zal voelen. Ook kent opgewektheid ('CHE') bij persoon B een lichte, positieve feedbackloop. Dit kan geïnterpreteerd worden als dat wanneer persoon B zich op het ene moment opgewekt voelt, hij zich op een later moment nog opgewekter zal voelen. Positief affect kent in het temporal netwerk van persoon B geen partiële correlaties. Deze knoop kent geen voorspellende relaties over tijd met de andere knopen in het netwerk. Afgaande op de centraliteitsplot van het contemporaneous netwerk van persoon B zijn tevredenheid ('SAT'), enthousiasme ('ENT') en ontspannenheid ('REL') de meest centrale knopen in het netwerk. Dit is terug te zien in de netwerkstructuur aangezien deze knopen relatief veel en sterke relaties hebben met de rest van het netwerk. Positief affect ('POS') kent in het contemporaneous netwerk de hoogste partiële correlatie met enthousiasme ('ENT') en de laagste partiële correlatie met irritatie ('IRR'). Dit houdt in dat op hetzelfde meetmoment positief affect en enthousiasme vaker samen voorkomen, en positief affect en irritatie minder vaak.

In Appendix A zijn zowel contemporaneous en temporal netwerken als gestandaardiseerde centraliteitsplots van nog twee personen (persoon C en D) met een $100 \%$ response rate terug te vinden.

Voor het schatten van de temporal en contemporaneous collectieve netwerken is ook gebruik gemaakt van reguliere BIC. Ook in dit geval geldt dat deze vorm van modelselectie het meest spaarzame model prefereert, maar minder spaarzame modellen niet extreem afstraft. Dit heeft ook hier als gevolg dat er een hoger aantal connecties in het model zullen worden geschat dan bij strengere modelselectiemethoden. De temporal 
en contemporaneous netwerken uit respectievelijk Figuur 6 en Figuur 7 zijn collectieve netwerkmodellen. Dit houdt in dat ze zijn geschat met data van alle 31 deelnemers uit deze studie. Hierdoor zeggen ze niet alleen iets één individu, maar over een bredere populatie. De geschatte netwerken zijn multivariate Vector Autoregressie (VAR) modellen met een lag-interval van 1. Dit houdt in dat alleen één meetmoment voor het huidige wordt gebruikt in de voorspelling van het huidige meetmoment. Voor het voorspellen van een waarde van een knoop in een middagsessie wordt dus alleen gekeken naar de voorgaande ochtend.
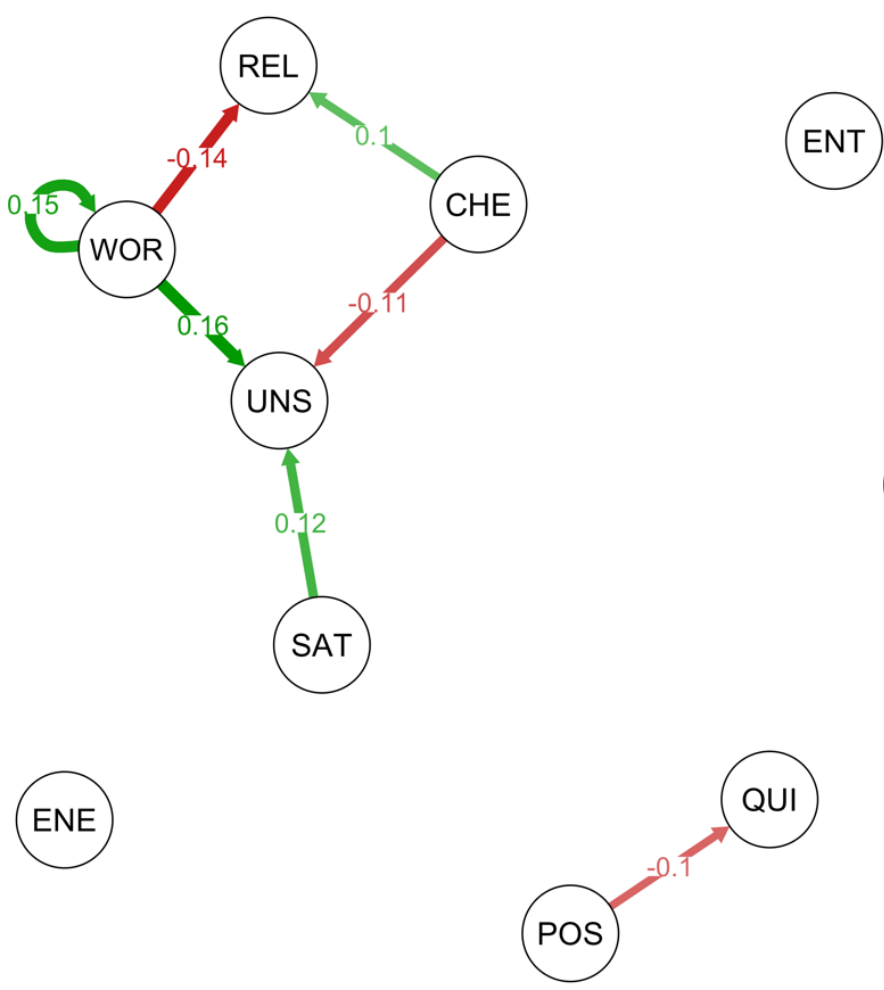

Figuur 6. Het Collectieve Temporal Netwerk, $N=31$.

In Figuur 6 is het collectieve temporal netwerk van alle deelnemers terug te vinden. In dit netwerk wordt gekeken naar de voorspellende waarden van knopen over tijd, aan de hand van partiële relaties. In het model valt op dat onzekerheid ('UNS') veel inkomende relaties kent, en dus in hoge mate over tijd kan worden voorspeld door 
andere affect-states. Het zich zorgen maken ('WOR') en geagiteerd zijn ('AGI') kennen een positieve feedbackloop. Dit houdt in dat ze zichzelf positief voorspellen. Dit betekent dat als iemand zich op het ene moment zorgen maakt, hij/zij zich op het moment erna waarschijnlijk nog meer zorgen maakt. Ook heeft iemand die op het ene moment geagiteerd is een grotere kans op het moment erna nog geagiteerder te zijn. Positief affect ('POS') kent een kleine negatieve partiële correlatie met het zich stil voelen ('QUI'). Dit houdt in dat iemand die op het ene moment positief affect ervaart, zich daarna waarschijnlijk minder stil zal voelen.

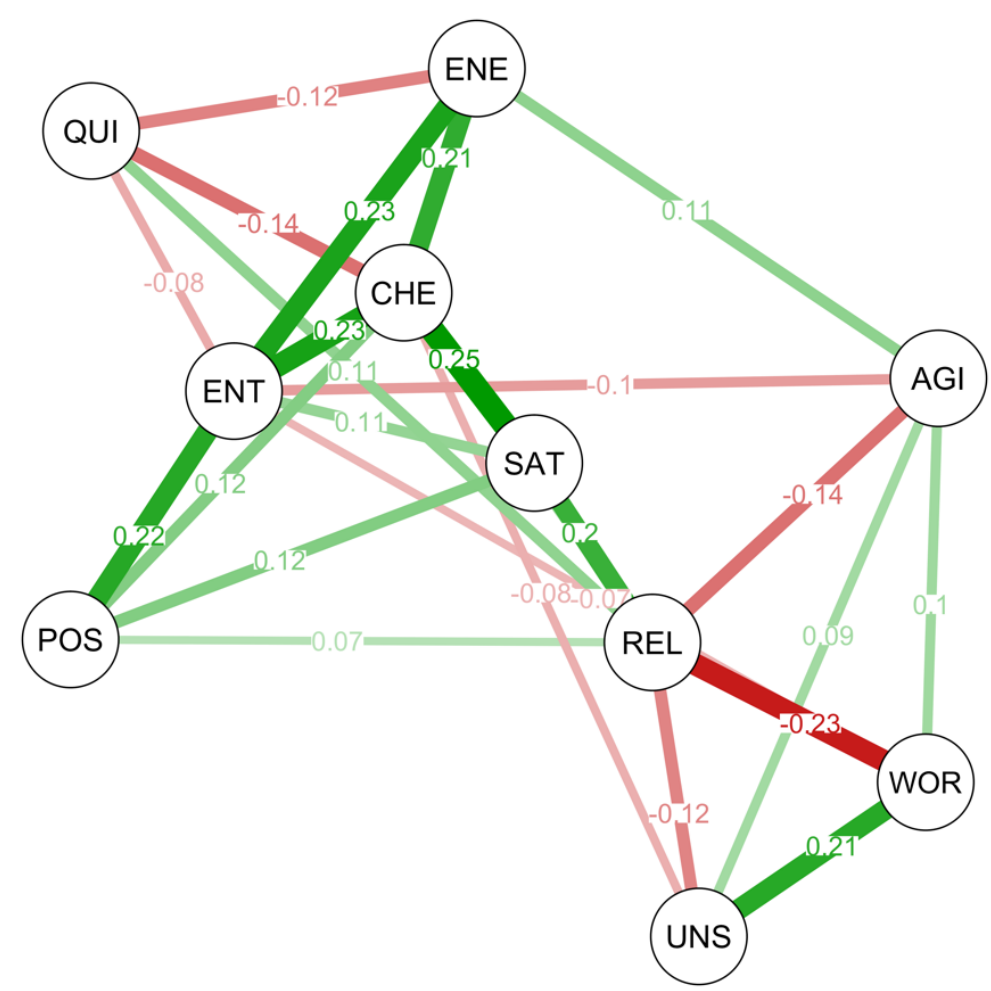

Figuur 7. Het Collectieve Contemporaneous Netwerk, $N=31$.

In Figuur 7 is het collectieve contemporaneous netwerk van alle deelnemers terug te vinden. Dit netwerk kent relatief veel relaties. Dit netwerk laat zien of knopen elkaar voorspellen binnen hetzelfde meetmoment. In dit netwerk is te zien dat enthousiasme ('ENT'), opgewektheid ('CHE') en tevredenheid ('SAT') centrale knopen zijn. Deze affect-states kennen veel relatief met de andere knopen in het netwerk. In dit 
netwerk is goed terug te vinden dat positieve emoties onderling veelal positief met elkaar correleren. Ook kennen positieve emoties meestal negatieve correlaties met negatieve emoties, zoals verwacht. Positief affect kent positieve partiële correlaties met enthousiasme ('ENT'), opgewektheid ('CHE'), tevredenheid ('SAT') en ontspannenheid ('REL'), wat inhoudt dat iemand die op een bepaald moment positief affect ervaart, een grotere kans heeft ook één of een aantal van deze emoties te ervaren.

In Appendix B is een codescript voor softwareomgeving $\mathrm{R}$ terug te vinden, met daarin alle code gebruikt voor het analyseren van de data en het schatten van de netwerkmodellen.

\section{Conclusie \& Discussie}

In de temporal en contemporaneous netwerken, van zowel beide individuen als het collectief van alle deelnemers, is te zien dat enthousiasme ('ENT') en tevredenheid ('SAT') een centrale rol spelen in de structuur. Ook komt overeen dat knopen die positieve emoties representeren vaak een positieve samenhang kennen met andere knopen van positieve emoties, en een negatieve samenhang met knopen die negatieve emoties representeren. Dit hangt samen met de broaden-and-build theory of positive emotions welke stelt dat dezelfde soort emoties vaak samen voorkomen en elkaar versterken. Of een causaal verband ook prevalent is tussen de knopen van één van de netwerken valt op basis van partiële correlaties niet te concluderen. Aangezien er wel partiële correlaties met richting werden waargenomen in de temporal netwerken kan gezegd worden dat, aangezien dit soort netwerken over tijdsintervallen wordt geschat, de gevonden correlaties wel degelijk een implicatie van causaliteit geven. Hiermee wordt bedoeld dat wanneer er in werkelijkheid een causale relatie is, er in een temporal netwerk ook een relatie zou worden verwacht (hoewel een relatie ook door andere 
factoren te weeg kan worden gebracht). Ook kan het voorkomen dat ondanks dat er in werkelijkheid een causale relatie is, deze niet in het temporal netwerk wordt opgenomen vanwege een gebrek aan statistische power of een ander type lag-interval (Epskamp et al., 2017).

Bij het schrijven van deze these zijn een aantal punten van discussie naar voren gekomen. De eerste is dat voor het schatten van alle getoonde netwerkmodellen een $\gamma$ parameter van 0 is gebruikt, voor lage afstraffing van connecties en lage sparsity. Dit heeft als eerste nadeel dat de weergegeven netwerken mogelijk enige vorm van overfitting op de data bevatten. Het tweede nadeel is dat er een verhoogde kans op een type II-fout ontstaat, waarbij een relatie in een netwerk wordt aangenomen, zonder dat deze is de werkelijkheid bestaat. Deze beslissing is te verdedigen met het gegeven dat deze studie een exploratieve studie is, welke inzicht wil geven in wat er mogelijk is op het gebied van netwerkanalyse van resilience, en met een lage $\gamma$-parameter er zo veel mogelijke relaties inzichtelijk worden gemaakt en hebben de netwerken een hogere exposerende waarde.

Het tweede punt van discussie is het behandelen van ontbrekende data. Aangezien de voor de collectieve netwerken gebruikte mIVAR-package moeilijk kan omgaan met ongelijke hoeveelheden meetmomenten van netwerkknopen zijn metingen waarbij slechts één of aan aantal vragen ontbraken in het geheel verwijderd. Dit heeft als gevolg dat mogelijk waardevolle data met voorspellende eigenschappen verloren is gegaan bij dit proces. Echter is dit de enige beschikbare package in de R-omgeving welke geschikt is voor de benodigde analyses, gezien de relatief nieuwe aard van netwerkanalyse binnen de psychometrie.

Het derde discussiepunt kwam ook naar voren bij het opschonen van de ruwe dataset. Bij het analyseren van de data kwam naar boven dat een aantal deelnemers 
langer dan nodig was doorgegaan met het invullen van de vragenlijsten op de app, en zo meer dan 42 metingen voltooide. Er is in deze gevallen voor gekozen alleen te kijken naar de eerste 42 meetmomenten, waarbij dus alle data die is verkregen doordat deelnemers te lang zijn doorgegaan is genegeerd. Hier is voor gekozen om alle deelnemers hetzelfde maximumaantal meetmomenten te geven in het analyseren van de individuele netwerken.

Het laatste discussiepunt is het verwijderen van de knopen boosheid ('ANG') en geïrriteerdheid ('IRR') in de twee collectieve netwerken. Dit is spijtig aangezien deze knopen nu niet zijn opgenomen in de uiteindelijke collectieve netwerkstructuren. Hier is voor gekozen omdat deze twee knopen de twee knopen waren die het minste variantie in de dataset kenden en de mIVAR package zonder het verwijderen van de knopen geen collectief netwerk kon schatten.

Voor toekomstig onderzoek is het goed als er wordt gekeken naar grotere aantallen participanten om met meer zekerheid en power uitspraken te kunnen doen over grotere groepen mensen. De uitspraken zullen dan meer generaliseerbaar zijn over een grotere populatie. Ook kunnen aan de hand van deze exploratieve studie belangrijke knopen in de netwerkstructuur van resilience worden geselecteerd, en kan worden gekeken naar combinaties met andere constructen in een netwerk.

Al met al kan worden geconcludeerd dat resilience een complex construct is, met een aantal naar voren springende centrale knopen in de netwerkstructuur. Positief affect is niet één van deze knopen met een hoge centraliteit, wat wel verwacht werd aan de hand van de broaden-and-build theory of positive emotions van Fredrickson (1998). Wel kent positief affect zowel in contemporaneous als temporal netwerken partiële correlaties met andere constructknopen in het netwerk, wat een lichte indicatie van causaliteit suggereert. 


\section{Literatuurlijst}

Aan het Rot, M., Hogenelst, K., \& Schoevers, R. A. (2012). Mood disorders in everyday life: A systematic review of experience sampling and ecological momentary assessment studies. Clinical Psychology Review, 32, 510-532. doi:10.1016/j.cpr.2012.05.007

Bonanno, G. A. (2004). Loss, trauma, and human resilience. American Psychologist, 59, 20-28. doi:10.1037/0003-066X.59.1.20

Borsboom, D. (2008). Psychometric perspectives on diagnostic systems. Journal of Clinical Psychology, 64, 1089-1108. doi:10.1002/jclp.20503

Borsboom, D. \& Cramer, A. O. J. (2013). Network analysis: An integrative approach to the structure of psychopathology. Annual Review of Clinical Psychology, 9, 91-121. doi:10.1146/annurev-clinpsy-050212-185608

Broyles, L. C. (2005). Resilience: Its relationships to forgiveness in older adults. Ongepubliceerd proefschrift, University of Tennessee, Knoxville.

Cramer, A. O. J., Van Borkulo, C. D., Giltay, E. J., Van der Maas, H. L. J., Kendler, K. S., Scheffer, M. S., \& Borsboom, D. (2016). Major depression as a complex dynamic system. Public Library of Science One. doi:10.1371/journal.pone.0167490

Epskamp, S. (2017). graphicalVAR: Graphical VAR for experience sampling data. Opgehaald van http://cran.r-project .org/package=graphicalVAR

Epskamp, S., Deserno, M. K., \& Bringmann, L. F. (2017). mIVAR: Multi-level vector autoregression. Opgehaald van https://cran.r-project.org/package=mlVAR

Epskamp, S. \& Fried, E. I. (2016). A tutorial on regularized partial correlation networks. Psychological Methods. doi:10.1037/met0000167 
Epskamp, S., Rhemtulla, M. T., \& Borsboom, D. (2017). Generalized network psychometrics: Combining network and latent variable models. Psychometrika. doi:10.1007/ s11336-017-9557-x

Epskamp, S., Van Borkulo, C. D., Van der Veen, D. C., Servaas, M. N., Isvoranu, A.-M., Riese, H., \& Cramer, A. O. J. (2017). Personalized network modeling in psychopathology: The importance of contemporaneous and temporal connections. Clinical Psychological Science, 1-12. doi:107.1177/2167702617744325

Fredrickson, B. L. (2001). The role of positive emotions in positive psychology: The broaden-and-build theory of positive emotions. American Psychologist, 56, 218226.

Fredrickson, B. L., Tugade, M. M., Waugh, C. E., \& Larkin, G. R. (2003). What good are positive emotions in in crises? A prospective study of resilience and emotions following the terrorist attacks on the United States on September 11 th 2001. Journal of Personality and Social Psychology, 84, 365-376.

Fredrickson, B. L. (1998). What good are positive emotions? Review of General Psychology, 2, 300-319.

Luthar, S. S., Cicchetti, D., \& Becker, B. (2000). The construct of resilience: A critical evaluation and guidelines for future work. Child Development, 71, 543-562.

Masten, A. S. (2001). Ordinary magic: Resilience processes in development. American Psychologist, 56, 227-238. doi:10.1037//0003-066X.56.3.227

Myin-Germeys, I., Oorschot, M., Collip, D., Lataster, J., Delespaul, P., \& Van Os, J. (2009). Experience sampling research in psychopathology: Opening the black box of daily life. Psychological Medicine, 39, 1533-1547.

doi:10.1017/S0033291708004947 
Nygren, B., Aléx, L., Jonsén, E., Gustafson, Y., Norberg, A., \& Lundman, B. (2005).

Resilience, sense of coherence, purpose in life and self-transcendence in relation to perceived physical and mental health among the oldest old. Aging \& Mental Health, 9, 354-362. doi:10.1080/1360500114415

Tugade, M. M. \& Fredrickson, B. L. (2004). Resilient individuals use positive emotions to bounce back from negative emotional experiences. Journal of Personality and Social Psychology, 86, 320-333. doi:10.1037/0022-3514.86.2.320

Van der Krieke, L., Emerencia, A. C., Bos, E. H., Rosmalen, J. G., Riese, H., Aiello, M., Sytema, S., \& De Jonge, P. (2015). Ecological momentary assessments and automated time series analysis to promote tailored health care: A proof-ofprinciple study. JMIR Research Protocols, 4, e100. doi:10.2196/resprot.4000

Wagnild, G. M. \& Collins, J. A. (2009). Assessing resilience. Journal of Psychosocial Nursing, 47, 28-33. doi:10.3928/02793695-20091103-01

Werner, E. E. (1995). Resilience in development. Current Directions in Psychological Science, 4, 81-85. 


\section{Appendix A}
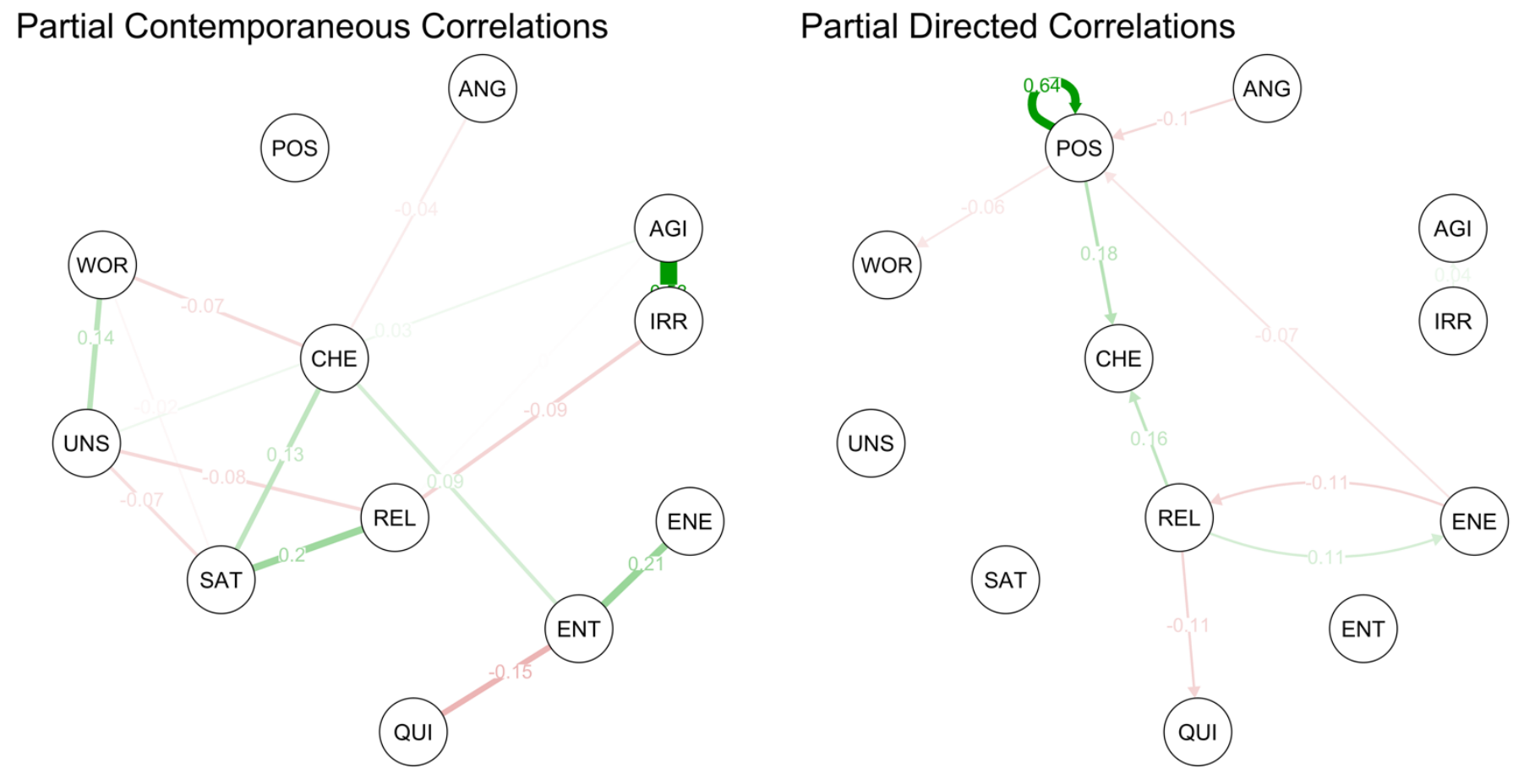

Figuur A.1. Netwerkstructuren van Persoon C. Links het Contemporaneous Netwerk, Rechts het Temporal Netwerk. 
Partial Contemporaneous Correlations

ANG

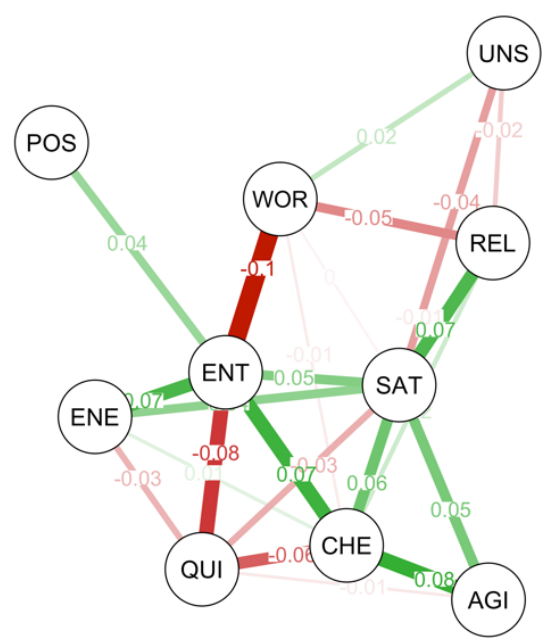

Partial Directed Correlations

ANG

UNS

POS

WOR

REL

IRR

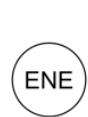

SAT

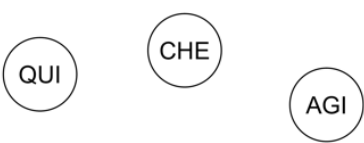

Figuur A.2. Netwerkstructuren van Persoon D. Links het Contemporaneous Netwerk, Rechts het Temporal Netwerk. 


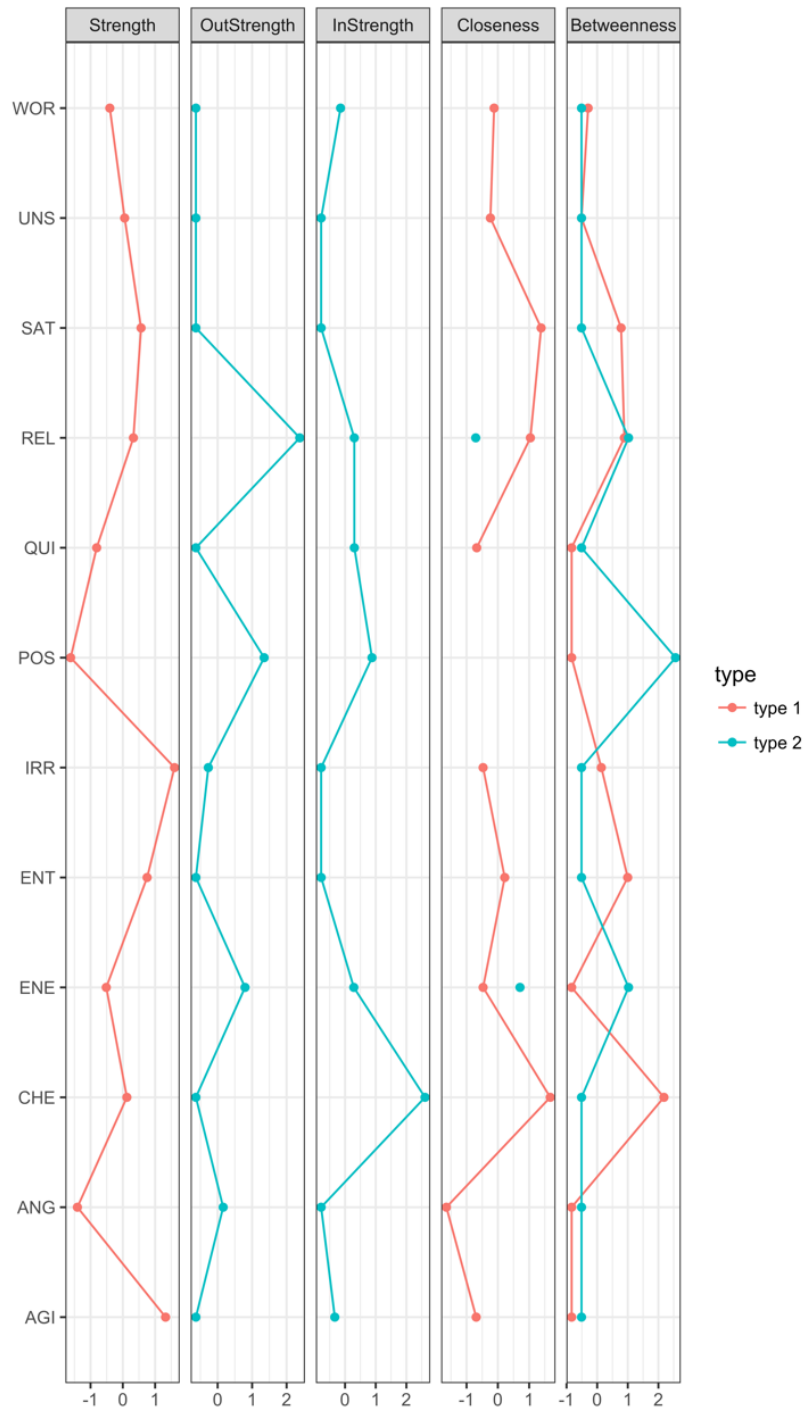

Figuur A.3. Gestandaardiseerde Centraliteitsplot Netwerkknopen Persoon C. De X-As Laat Z-Scores Zien.

Type 1 = Contemporaneous Netwerk, Type 2 = Temporal Netwerk

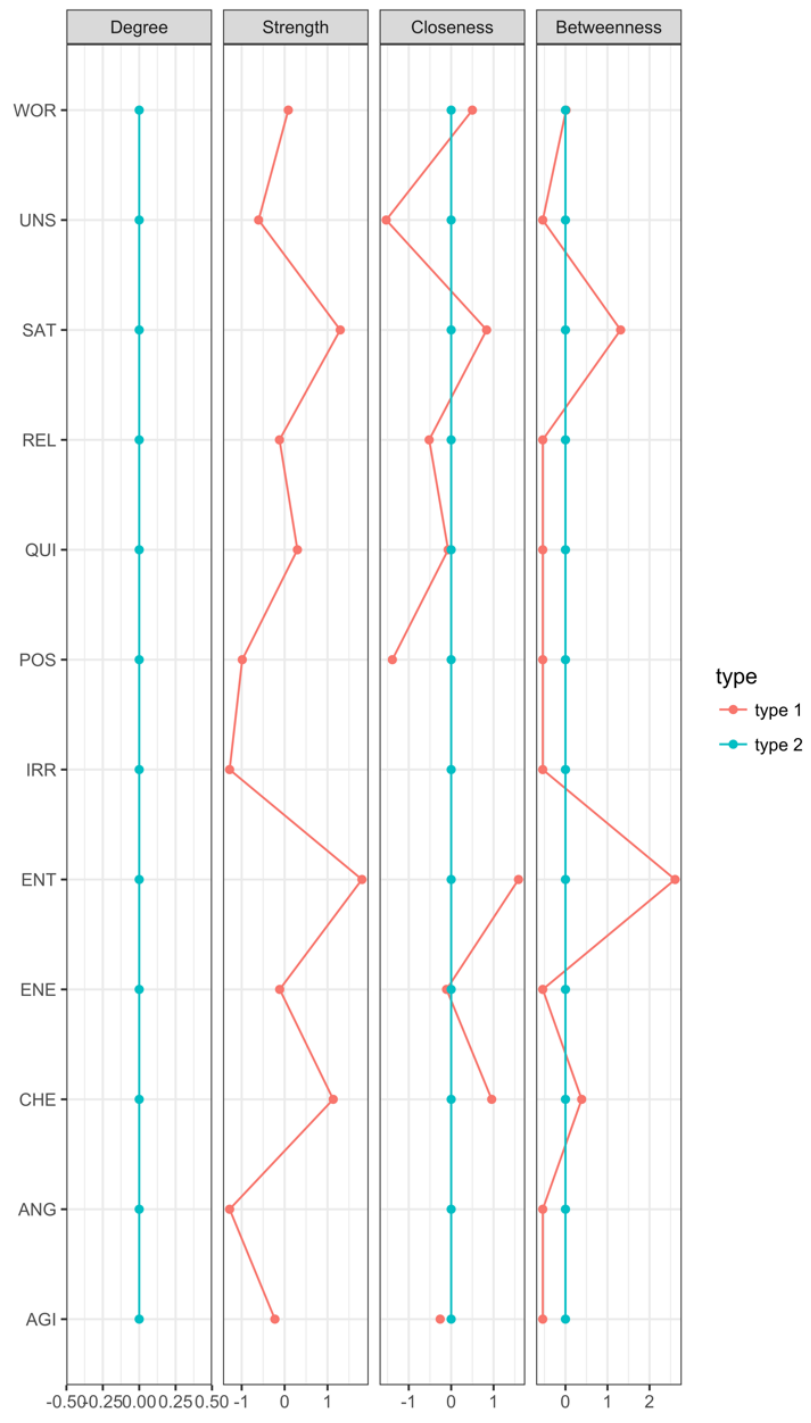

Figuur A.4. Gestandaardiseerde Centraliteitsplot Netwerkknopen Persoon D. De X-As Laat Z-Scores Zien.

Type 1 = Contemporaneous Netwerk, Type 2 = Temporal Netwerk 


\section{Appendix B}

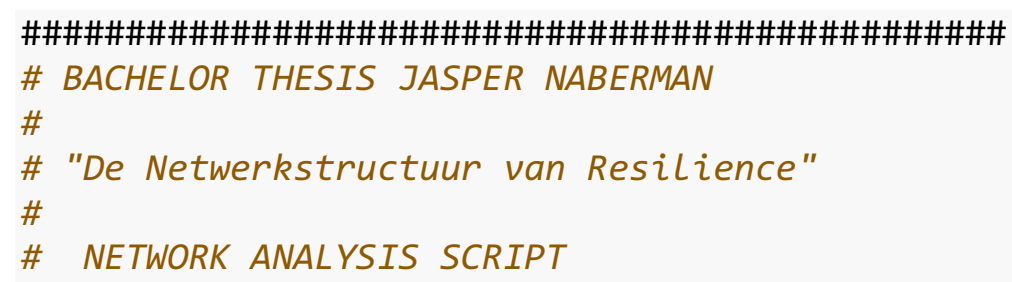




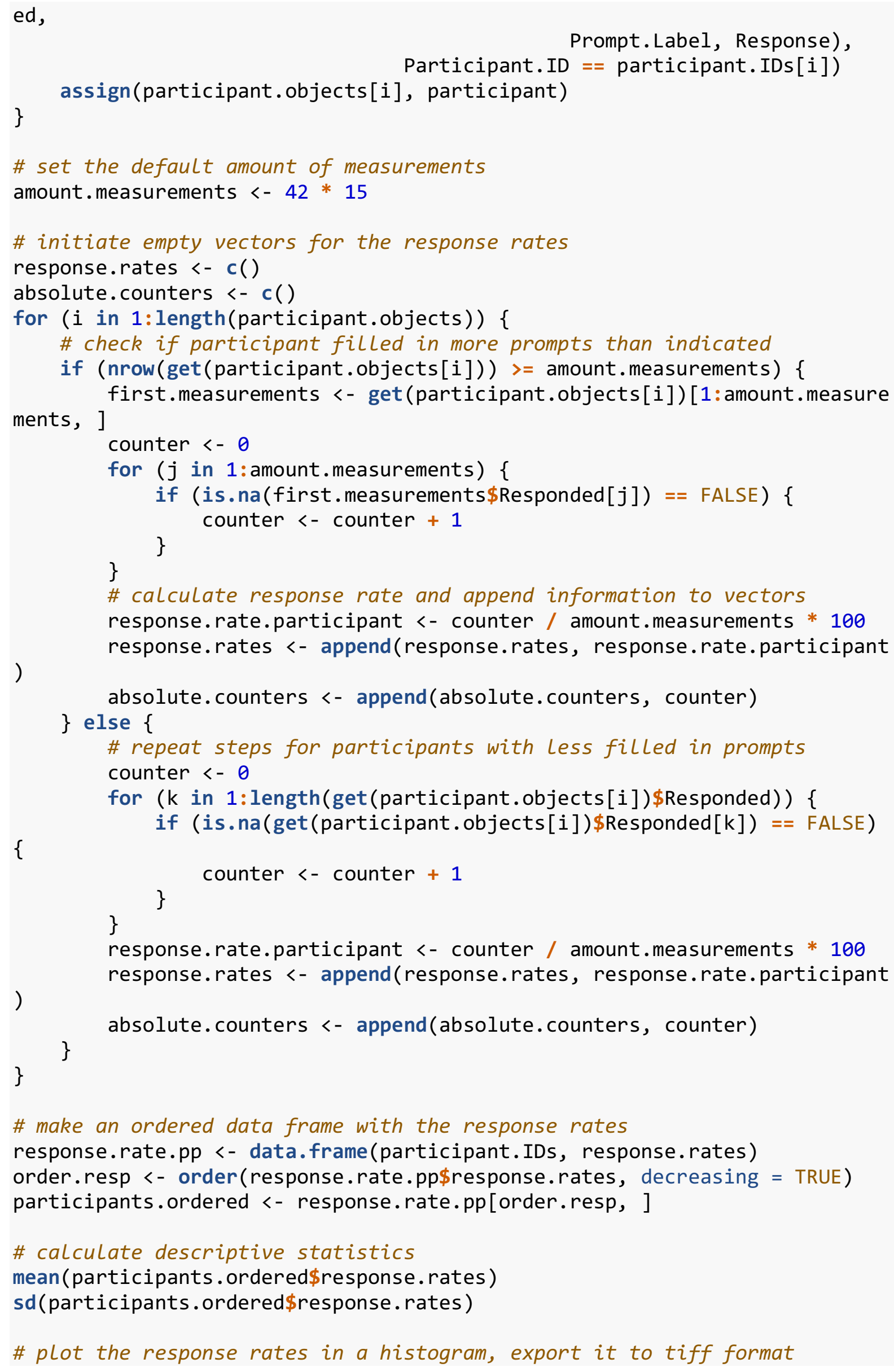


hist (participants.ordered\$response.rates, $y \lim =\operatorname{range}(0: 25)$, main = "Response Rates", labels = TRUE, $\mathrm{xlab}=$ "\% Beantwoorde Meetmomenten", ylab = "Frequentie Deelnemers", col = colorRampPalette $(c($ "yellow", "red"))(7))

\# calculate the absolute response rate

abs.amount.responses <- sum(absolute.counters)

abs.amount.measurements <- amount.measurements * length(participant.IDs)

abs.response.rate <- abs.amount.responses / abs.amount.measurements * 100

\# filter out the participants with a $100 \%$ response rate

part.IDs.100 <- participants.ordered\$participant.IDs [1:max (which (participa nts.ordered\$response. rates $==100)$ )]

\# remove all participants which might have 'skipped' a prompt

for ( $i$ in 1:length(part.IDs.100)) \{ resp.col <- get(paste(c("ID.number.", part.IDs.100[i]), collapse = " ") )\$Responded for ( $j$ in $1:$ length (resp.col)) \{

if (resp.col[j] != 1) \{

remove <- part.IDs.100[i] \} part.IDs.100 <- part.IDs.100[!part.IDs.100 \%in\% remove]

\}

\#

\# Script Person A

\#

\# select one of the participants with the highest response rates

participant <- dplyr::filter(dplyr: :select(daily.survey, Participant.ID, D ate,

1 , Time, Session. Name, Prompt.Labe

rt.IDs.100[1])

Response), Participant. ID $==p a$

\# sort the promt and responses by date and time

sort.date <- group_by(participant, Date)

participant <- arrange(sort.date, Time, .by_group = TRUE)

\# seperate all the promps by their labels and assign them to a variable

for (i in 2:length(levels(participant\$Prompt.Label))) \{ assign(levels (participant\$Prompt.Label) [i], dplyr: : filter(participant,

i]) $[, 6][1: 42]$,

Prompt.Label == levels (participant\$Prompt.Label) [

\}

\# make a data frame fit for the graphicalVAR package

df <- data.frame(Relaxed, Quiet, Satisfied, Unsure, Enthusiast, Cheerful, Agitated, PosAff, Worrying, Energy, Irritated, Angry) $\operatorname{names}(d f)<-c($ 'REL', 'QUI', 'SAT', 'UNS', 'ENT', 'CHE', 'AGI', 












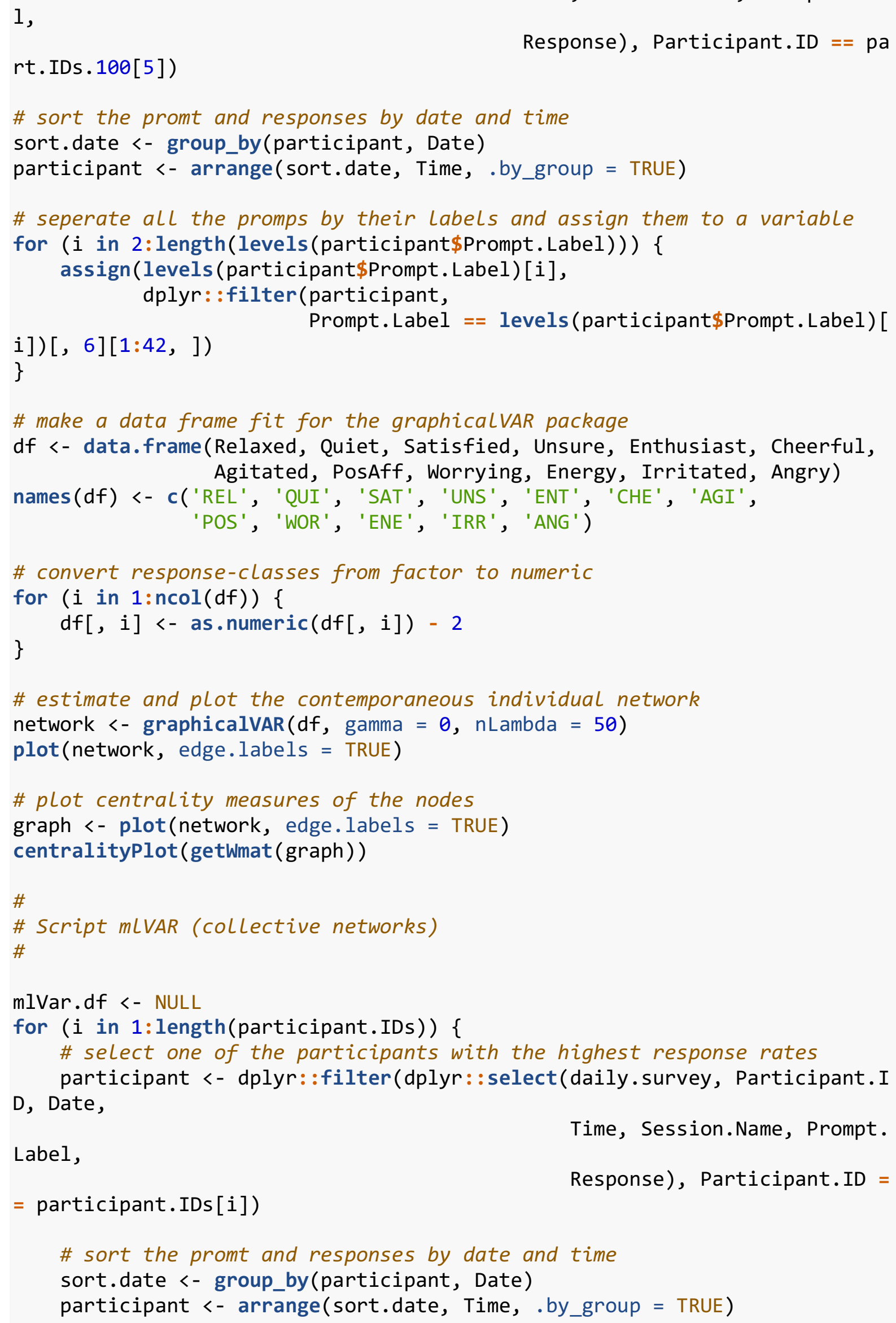




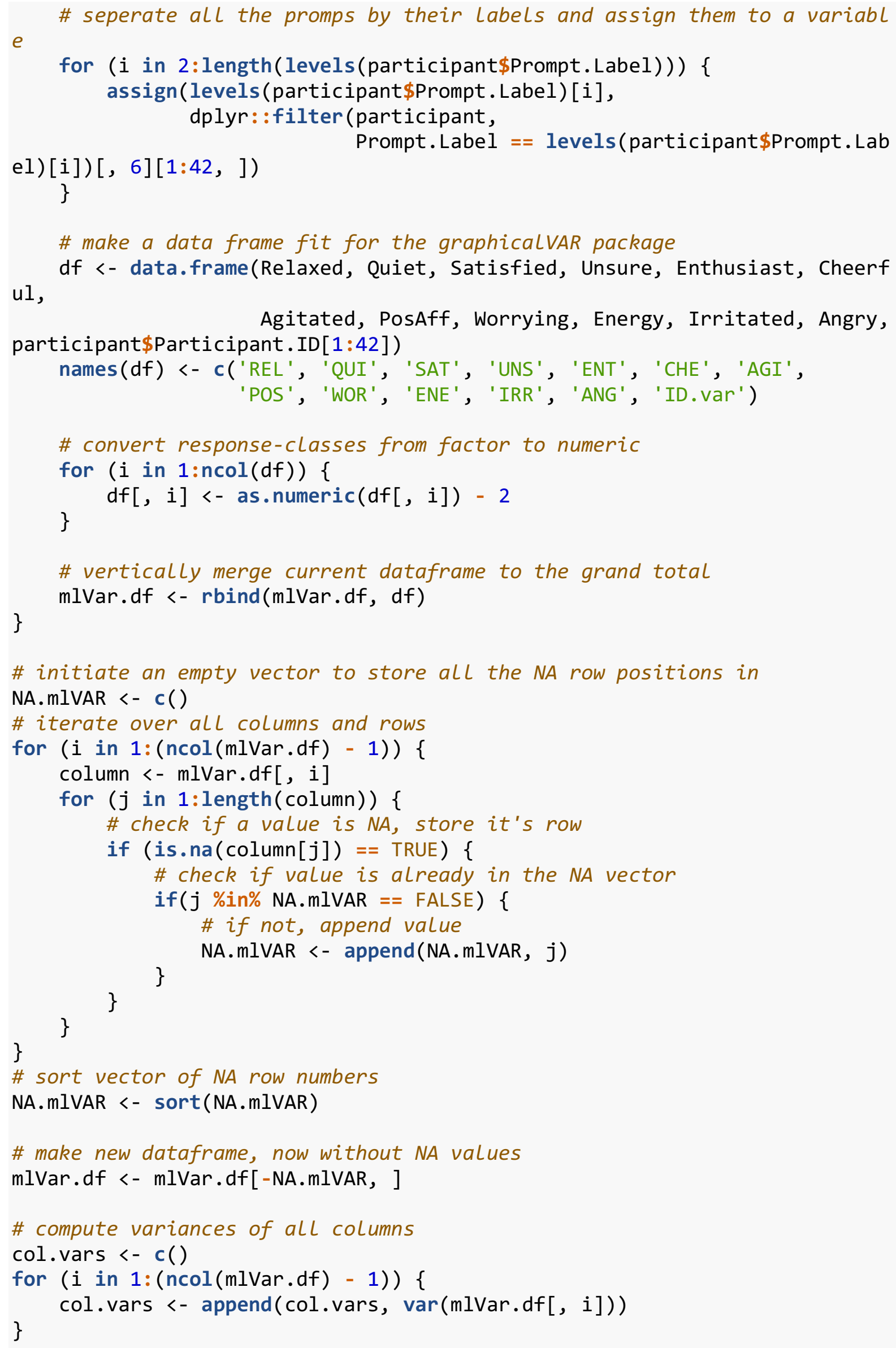




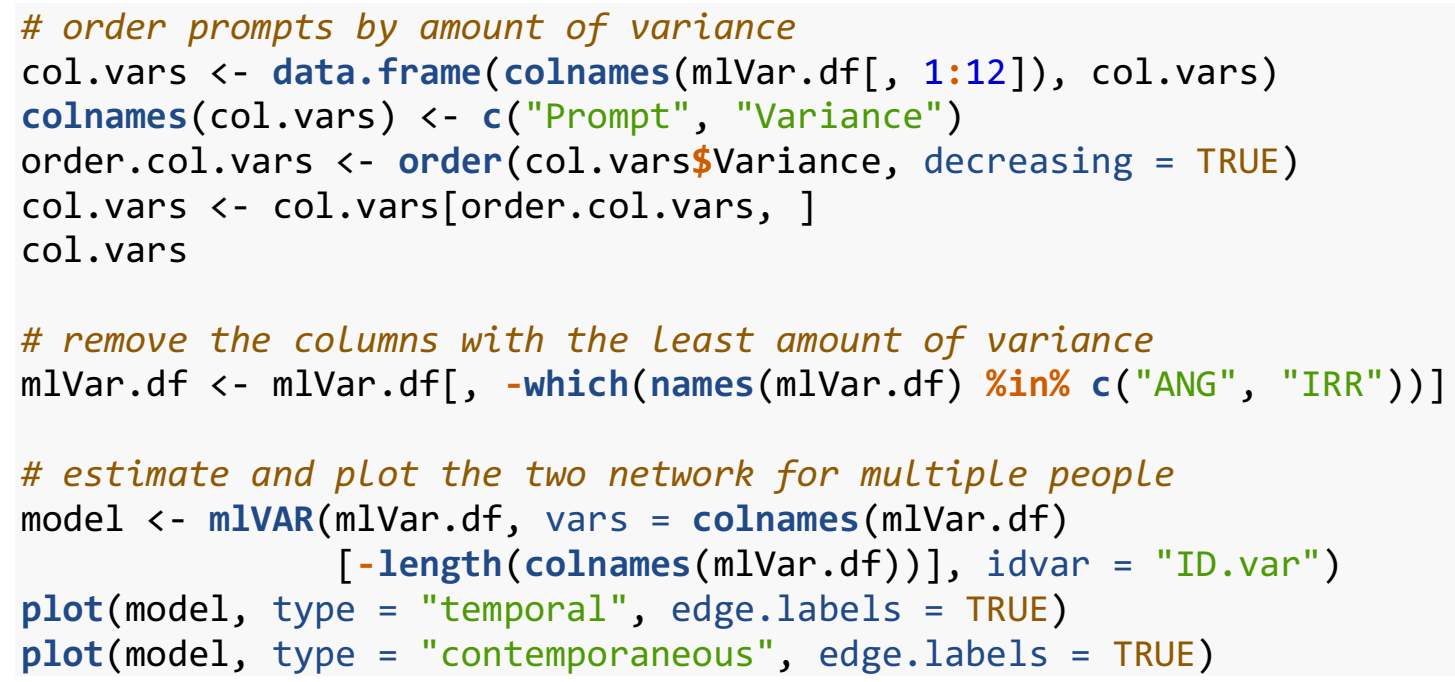

